\title{
Emergence of Private Sector in the Provision of Social Services in Nigeria: Moving Social Services Beyond Government
}

\author{
Randy Oyovwevotu Sakpere \\ Department of Public Administration, Obafemi Awolowo University Ile-Ife, Nigeria
}

\begin{abstract}
The inability of various levels of government in Nigeria to fulfil their obligations in the provision of social services has resulted in the emergence of the private sector as an active participant in the delivery of social services in Nigeria. Even though the provision of social services has historically been considered exclusively state function, the 1990s saw the emergence of the private sector involvement in the provision of social services. This paper examines the role of the private sector as either a partner or a separate entity in delivering social services in Nigeria and assess the effect of private sector on the provision of social services. Data for this study were drawn from questionnaire, interviews and observation obtained from nongovernmental organizations (NGOs), civil societies (CSOs), community based organisations (CBOs) and local and state Governments' agencies saddled with provision of social services in the country. The results showed that the private sector is emerging as important players and is increasingly providing social services. The results also revealed increasing role of the private sector in the management and delivery of social services in Nigeria. The paper concluded that a framework for further cooperation will promote public-private partnership (PPP) in delivering social services in Nigeria.
\end{abstract}

Key words: Private sector, Provision, Social services, PublicPrivate Partnership, Participation.

\section{INTRODUCTION}

I mmediately after the second world war, most governments in the developed and developing countries delegated delivery of social services to public sector/government departments and state owned enterprises (Grimsey, 2002; Harris 2003). Delivery of social services all over Europe was wholly the function of the state up to the 1970s. Afterwards, most countries in Europe have expanded the role of the private sector to include delivery of certain services that was once the traditional role of government (Eurofound, 2015). This action was necessitated by the need to enhance quality, accessibility and efficiency of social services. However, in Africa and especially Sub-Saharan Africa, provision of social services is still majorly the responsibility of government, unlike the current practice in Europe resulting in poor service delivery as a result of poor implementation.

The emergence of private sector as a key participant in delivering social services in countries in Europe has resulted in efficient and effective social services delivery. Thus, the situation in Nigeria, where government expenditure in social services is deficient in meeting the needs and demand of the growing population has shown that government alone can no longer exclusively be responsible for providing social services. As a result, the inadequacy of social services in Nigeria is responsible for the country's poor ranking as having the worst human development indicators in Africa (IRIN, 2007). The inadequacy of these services has limited their accessibility by citizens they are expected to serve. Alluding to this assertion, Igbuzor (2010) opined that poor access to facilities and infrastructure at all levels is due to their inadequacy. However, this system of procuring infrastructure and delivering public services proved unsustainable as the public sector organisations empowered with authority were characterised by insufficient government investments, budget deficits, inefficiencies, poor pricing policies, corruption, overstaffing, mismanagement, and stagnation (Harris, 2003, Rwelamira 2004) and therefore did not provide value for money to the public clients. Hence in the last three decades, governments, both the developed and the developing world have been moving away from the traditional approaches; where government is solely and completely involved, to alternative arrangements that embrace more private sector involvement, in provision and delivery of public service.

A joint report produced by the United Nations Children's Fund (UNICEF) and WHO in 2006 revealed a decline in accessibility to clean and potable water across Nigeria, which dropped from $49 \%$ in 1990 to $48 \%$ in 2004 . However, as at 2021, accessibility to clean and potable water has dropped further due to poor budgeting to this sector. The report which forecasted back then in 2006 that Nigeria was unexpected to attain the Millenium Development Goals (MDGs) eventually occurred, since the 65 per cent coverage required in 2004 to meet the target was never achieved (IRIN, 2007). Nigeria eventually failed to attain the MDG, especially in poverty reduction, accessibility to clean and potable water, reduction in out of school children, infant and maternal mortality etc. in 2015. The epidemic outbreak of cholera in some states between March to October 2017 and between March to August 2018, attest to poor access to clean and potable water.

In addition, data from Integrated Regional Information Network (IRIN) indicated that only 10 per cent of rural dwellers and 40 per cent of urban dwellers could access electricity in Nigeria. Furthermore, due to the poor health 
facilities and inability of most Nigerians to access affordable healthcare, majority $(60 \%)$ of the nation's populace have recourse to traditional medicine for help. In the same vein, the poor state of education in the country has led to the rise in out of school children from 10.5 million in 2014 to about 14.5 million in second quarter of 2021 due to insecurity, large scale poverty, and infrastructural financing gap. The World Bank (2008) reported that 53 percent of urban population have access to good sanitation while only 36 percent of rural dwellers have access to good sanitation.

Significant changes have taken place in the provision of social service in Nigeria in the last three decades. This change process is strongly connected with a progressive "shift in paradigm", from government to private sector as the best provider of social services. In the light of this deficit in the provision of social services, this paper examines involvement of private sector organisations in the provision of social services in Nigeria, as well as assess private sector influence on social service provision in Nigeria.

\section{LITERATURE REVIEW}

Neoliberal policy has emerged as one of the most fundamental policy shifts since the 1980 s, due to its emphasis on commercialisation of social service delivery. Motivated by lack of funding by governments and agitations for market liberalisation, the process of commercialisation occurred in various forms. These include outsourcing management of social service to competent private sector organisations, and the inception of cost recovery mechanisms such as user fees which requires out of pocket payments (UNRISD, 2007).

Involvement of the state actors and the private sector organisations (for profit and not for profit organisations) in the delivery of services is crucial to understanding and managing the politics of service delivery. The concept of the private sector can convey different meanings to different scholars. This may be attributed to the diverse nature of the concept which makes it challenging to differentiate this sector from other forms of association. This conceptualisation of the private sector and delivery is an aftermath of the distinct history and environment of social service delivery in a developing country like Nigeria.

Institutions of government have engaged themselves in a tussle of supremacy between the various social groups (Thompson, 1995). These actions have negatively impacted the delivery of social service to the society. In Nigeria for example, the exacerbating of insecurity has been attributed to lack of cooperation and synergy among the security agencies due to supremacy contest among them. Public service delivery has been associated with provision of public goods or social (education, health), economic (grants) or infrastructural (water, electricity) services to members of the society who needs these services. The current approaches acknowledge the private sector as a stakeholder, partner or an independent organisation in providing such basic social services such as education, health care, water and sanitation is an emerging paradigm.

Organisations that are referred to as private sector include: (a) for-profit private business/corporate organisations, and (b) not-for-profit civil society organizations (CSOs) and/or nongovernmental organizations (NGOs). With the increasing demand for social services, urban and rural dwellers have seen the private sector as a significant provider of social services (Ugaz, 1997). Various rationale has been postulated for the rising significance of social development.

Social service is an array of plan of action directed at attaining some objectives and it relates to the social system in the goals of social policies. The purpose of social policies is to bring about positive change in the structure and living conditions of the people in the society. Government agencies ae responsible for delivering social service in order to improve the living conditions of people and the entire community. And services that enhances welfare of the people and community include housing, child protection, free health care and education (Ayo, 1988)

Social service is a broad concept which brings about enhancement in the well-being and welfare of people and society at large. It expedites the delivery of services such as healthcare, good education, housing, good road networks, clean potable water and electricity. It also involves poverty reduction, enhancing welfare of women and workers (Olewe and Anga, 1994). Geol (1981) advocates that social service is an approach that revolve around enhancing welfare of the community by applying the principles of social change and the execution of social policy decisions in order to achieve communal welfare. It involves every measures, strategies or tactics and contemplation in the course of action needed to impact social policy.

In the same vein, Donnison (1968) affirms that social legislations are directed at private philanthropy and faith based charities in order to enhance their effectiveness for social services delivery, so that their efforts can be of tremendous benefits for humanity. At present, Nigeria has not developed legal framework for public - private partnership, hence, the private sector has not wholly intervened in provision of social service at the level of communal effort, corporate social responsibility and philanthropy gesture of faith based organisations and individuals.

Todaro and Smith (2007) admitted that in the development context, civil society organizations are also referred to as nongovernmental organizations. This implies that NGOs attract recognition due to their involvement and commitment to improving the standard of life in the society. programs and activities. In like manner, World Health Organization (WHO, 2002) was of the view that, apart from NGOs, civil society also include only NGOs but also include many civil society actors. In line with the above disposition, WHO (2002) conclude that civil society is a social domain that is not part of the state or the market because the authoritative and 
supervisory power of the state and the economic power of market actors are non-existent in the civil society.

Advisory Group on Civil Society (AG-CS, 2007) describes the notion of civil society as incorporating a wide range of organizations that includes all non-market and non-state organizations and structures in which people organize to pursue shared objectives and ideals. In their interaction with the state and the market, civil society deploys social power in its actions. Social power constitutes the values of civil society which involve innovative ideas, information, services, and expertise (WHO, 2002).

Governance is the totality of the manner individuals and institutions, public and private, administer their common affairs. Asian Development Bank (ADB) observes that governance involves interaction with the institutional environment in which citizens interact among people and the officials of governmental agencies within an institutional environment. The determinant in realizing economic policies is dependent capacity of this institutional environment is important for development because it helps determine the impact achieved by the economic policies is dependent on capability and efficiency for achieving development of the institutional environment that government adopts.

\section{i. $\quad$ Social Service Delivery}

In Nigeria, government expenditure in the provision of social services could no longer meet the demands of the ever growing populace. Especially, at this period of economic recession, the government has found an excuse on why it cannot provide adequate social services either in the urban centres or at the rural areas. As a result, a great number of the population are denied accessibility to basic social services. A key function of government is to provide social services or public goods (Okojie, 2009).

The Copenhagen Declaration on Social Development, adopted by the World Summit for Social Development in 1995, involved a number of treaties destined for advancing social development and delivering social services to the people devoid of injustice (Economic and Social Commission for Asia and the Pacific, ESCAP, 2001). After the Copenhagen proclamation, the inclusion of social development in the decision on resource allocation have attracted endorsements which has caught the attention of nations of the World and multilateral agencies to concentrate their interest and efforts on issues of social development. Significant changes have taken place in the provision of social service in Nigeria in the last three decades. This change process is strongly connected with a progressive "shift in paradigm", from government to private sector as the best provider of social services.

Despite the fact that basic public services have traditionally been the major function of the state, the 1990s witnessed a paradigm shift noticeable in the emergence of private sector in delivering a range of social services that had hitherto been the responsibility of governments. Such action of contracting to the private providers prompted by compulsion to decrease the cost of service provision on the budget. The World Bank and other bilateral and multilateral development financing agencies for low- and middle-income countries such as Nigeria promoted reform packages such as involving private participation in the delivery of basic public services. These reforms were predicated on the notion that private participation in the provision of basic public services will reduce expenditure cost on government budgets, which the private sector is more suitable and competent to deliver, whereas the governments' role should be restricted to creating an enabling environment by stimulating and controlling the private sector activities (Hensher \& Stanley, 2002).

Civil society organisations have played an increasingly significant role in delivering public services since the early 1990s. With the gradual decline in the ability of the State to provide basic public services in Nigeria, the emergence of the civil society organisations as veritable option proves to be a useful option in delivering basic social services in health, sanitation, education, policing, utilities, infrastructure and transport etc.

\section{METHODOLOGY}

The research was a cross- sectional study that analysed policy documents and implementation reports from government and the civil society organisations (CSOs). The study also analysed primary data obtained from questionnaire, in-depth interviews, field observations, and intensive literature study using mixed methods. Multi-stage sampling technique was utilised for this study, and the first stage involved the stratification of the entire country into the six geopolitical zones namely: North-central, North-east, North-west, Southeast, South-south, and South-west. In the second stage, one state was randomly selected from each geopolitical zone namely: Oyo in south-west; Anambra in south-east; Delta in south-south; Kwara in north-central; Adamawa in north-east; and Sokoto in north-west.

At the third stage, stratified random technique was used in selecting one local government area (LGA) from each state totalling 6 LGAs in all, while two rural communities were selecting from each local government area (LGA) of the selected state. The selected communities and their local government areas are Ejinadu and Umudunu communities of Idemili Local Government Area in Anambra State (SouthEast), Orhuwhorun and Aladja communities of Udu Local Government Area in Delta State (South-South), Arologun and Moniya communities of Akinyele Local Government Area in Oyo State (South-West), Esie and Iloffa communities of Irepodun Local Government Area in Kwara State (NorthCentral), Bokka and Mutse communities of Michika Local Government Area in Adamawa State (North-East) and Gidan Kirya and Gidan Magaji of Binji Local Government Area in Sokoto State. At the third stage, proportionate random technique was adopted in selecting a sample of 732 respondents. Interviews were conducted with leaders of 
community development associations (CDAs) in each community of the selected state. Data collected were analysed using Pearson Correlation, ANOVA and Multiple Regression.

\section{RESULTS AND DISCUSSION}

Pearson correlation was adopted in deriving the extent of relationship between the dependent and independent variables. Also, regression analysis was used to derive effect of the independent variable (Private Sector Participation) on the dependent variable (Social Service Delivery).

\section{i. Involvement of Private Sector in the Provision of Social Services in Nigeria}

Results shows that the private sector has been significantly involved in the provision of social services in Nigeria. The result in Tables 1 and 2 shows that the private sector involvement in the provision of social services is positive and significant $\left(\mathrm{R}=.394 ; \mathrm{R}^{2}=.155 ; \mathrm{R}^{2}\right.$ (Adj. $)=.133 ; \mathrm{F}=$ $7.200 ; \mathrm{p}<.05)$. This implies that $15.5 \%$ of the total variance of social services was accounted for in the provision of electric poles, transformers, primary health facility and blocks of classrooms.

\begin{tabular}{|c|c|c|c|c|c|c|}
\hline \multicolumn{7}{|c|}{ Table 1: Analysis of Variance on the influence of Private Sector in the } \\
Provision of Social Services
\end{tabular}

Source: Author's Computation

Table 2: Regression Analysis on the involvement of Private Sector in the Provision of Social Services

\begin{tabular}{|c|c|c|}
\hline \multirow{4}{*}{ Equation 1 } & Multiple R & .394 \\
\cline { 2 - 3 } & R Square & .155 \\
\cline { 2 - 3 } & Adjusted R Square & .133 \\
\cline { 2 - 3 } & Std. Error of the Estimate & 1.070 \\
\hline
\end{tabular}

Source: Author's Computation

ii. The Extent of Involvement of Private sector in the Provision of social services in Nigeria
The result in Table 3 shows Pearson correlation coefficient on the degree of involvement of private sector in the provision of electric poles as .601. This according to Davis (1971) as shown in Table 4 implies that the private sector has been moderately involved in the provision of electric poles for electrification of communities in Nigeria. Affirming this view, the Deputy Director of Works in Saki East local government council established that the private sector has only been involved in replacement of electric poles, not really providing the poles for rural electrification in Oyo state.

In the same vein, a Pearson correlation coefficient of .377 on provision of primary health care facility indicates that the private sector involvement is weak. This means that the private sector has not performed very well in the building of new primary health care facility. The result is somewhat inconsistent with previous studies which found that private sector is strongly involved in the provision of primary health care facility in some countries (European Union Micro Project Programme, 2009; Ogba, 1991). One possible justification for the inconsistent result of this study is due to paradigm shift from donating healthcare facility in public owned health centre to starting a private healthcare service delivery centre. A community leader in Nafada local government area of Gombe state during interview asserted that the state of primary health care facility is very poor, hence members of the community patronizes traditional herbal practitioners.

Furthermore, a correlation coefficient of .490 on provision of transformers indicated that the private sector involvement is moderate. This was affirmed by interviews conducted with community leaders in Nassarawa and Enugu states that through communal efforts and /or CSOs/individuals' transformers were provided by communities. Also, a correlation coefficient of .561 on construction of feeder roads revealed that the private sector was moderately involved in the provision of feeder roads in the communities. A correlation coefficient of .442 on the provision of blocks of classrooms for primary and secondary schools implies that the private sector has been moderately involved in the provision of blocks of classrooms for primary and secondary schools in the selected states. Table 5 shows various social services provided by private sectors across communities in Nigeria.

Table 3: Correlation Analysis of the Bivariate Association between Private Sector and Social Services Provided

\begin{tabular}{llcc}
\hline S/N & \multicolumn{1}{c}{ Social Services } & Pearson Correlation (r) & Sig. (2-tailed) \\
1. & Provision of Electric Poles & .601 & .000 \\
2. & Provision of Primary HealthCare Facility & .377 & .000 \\
3. & Provision of Transformers & .490 & .000 \\
4. & Provision of Feeder Roads & .561 & .000 \\
5. & Provision of Blocks of Classrooms & .442 & .000 \\
\hline
\end{tabular}

Source: Author's Computation 
Table 4: Correlation co-efficient range showing strength of Association

\begin{tabular}{ll}
\hline Correlation Range & Strength of Association \\
$\pm 0.70- \pm 1.00$ & Strong \\
$\pm 0.40- \pm 0.69$ & Moderate \\
$\pm 0.25- \pm 0.39$ & Weak \\
$\pm 0.10- \pm 0.24$ & Very Weak \\
$\pm 0.00- \pm 0.09$ & None \\
\hline
\end{tabular}

Source: Adapted from James A. Davis, Elementary Survey Analysis. Englewood Cliffs, NJ: Prentice-Hall, 1971, 49.

\section{iii. Effect of Private Sector Participation (PSP) on Social Service Provision (SSP) in Nigeria}

The inadequacy of government to make provision in respect to the growing population has led to the adoption of self governing techniques by the private sector through collective action known as Community - Based Organizations (CBOs) or Non - Governmental Organizations (NGOs). The results of effect of Private Sector Participation (PSP) on Social Service Provision (SSP) in Nigeria are presented in Table 5 by regressing Social Service Delivery and its ten factors on Private Sector Participation.

As shown in Table 5, PSP was found to have insignificant positive effect on accessibility at $95 \%$ level of significance ( $t=$ $1.310, \mathrm{p}>.05)$. This implies that services provided cannot be accessed and used by all citizens who need them, thus, not all citizens could access social service in the society. This result was in consonants with the findings of Chiriacescu (2012) who affirm that ensuring that all class of people could access services in all communities has remained a mirage in South East Europe and Sub-Saharan Africa. These findings were corroborated by interviews assertion by some residents of Ejinadu and Umudunu communities of Idemili Local Government Area in Anambra State (South-East), Orhuwhorun and Aladja communities of Udu Local Government Area in Delta State (South-South), Arologun and Moniya of communities of Akinyele Local Government Area in Oyo State (South-West), Esie and Iloffa communities of Irepodun Local Government Area in Kwara State (NorthCentral), Bokka and Mutse communities of Michika Local Government Area in Adamawa State (North-East), and Gidan Kirya and Gidan Magaji of Binji Local Government Area in Sokoto State (North-West). They were of the view that vulnerable people i.e. pregnant women, elderlies with health problems and the physically challenged (those with disabilities) are not taking into consideration when the government and private sector are providing services. This makes accessibility to these services almost impossible. In some cases, where services are provided, they are sited at the outskirts of the communities, thus, the poor and/or vulnerable do not have the resources to access these services.
PSP was also discovered to have an insignificant positive effect on availability of social services at the $95 \%$ level of significance $(t=0.270, p>.05)$. The result indicates that there was no significant relationship between PSP and availability of social services. This alludes to the fact that some social services may exist and are not available to citizens when needed. The result was in agreement with the findings of Onokerhoraye (1999), who affirms that need for equity in the planning and distribution of services over the years have not attract profound attention in Nigeria, resulting in inadequate distribution and provision of services in Nigeria. However, regions with difficult terrain and physical environment suffers neglect

PSP was observed to have an insignificant positive effect on affordability at $95 \%$ level of significance $(t=0.371, \mathrm{p}>.05)$. This discloses that some services exist and are not provided for free or at an affordable cost to citizens when needed. This view was validated by responses of some community members in Oyo, Delta and Adamawa states in an interview. They averred that the cost of accessing good health and quality education is quite high and above the reach of the rural dwellers who settles for the poor and less quality services.

In addition, PSP was found to have insignificant positive effect at 95\% level of significance on accountability $(t=0.965$, $\mathrm{p}>.05$ ). This indicates that Service providers (PSP) are not financially and organisationally transparent (Accountability) in service delivery. This result authenticates the findings of Bold, Collier and Zeitlin (2009) who argued that many NGOs and even government could not account for funds released to them for service delivery. Nevertheless, while the NGOs performance have been adjudged to be average compared to that of government which is very poor in service delivery except for a few states with Rivers State leading the pack, the residents at the community level, thus look to NGOs rather than to the government for basic services.

Furthermore, PSP was discovered to have an insignificant negative effect on sustainability at $95 \%$ level of significance $(\mathrm{t}=-1.371, \mathrm{p}>.05)$. This infers that services provided are not improving resulting in increasing poor social services delivery (Unsustainability). This is the case in the electricity sector. Despite the privatisation of the electricity distribution sector, delivery of service to consumers continue to depreciate while cost of service delivery continue to surge. Thus, the level of sustainability of electricity supply is inverse and retrogressive.

PSP was observed to have an insignificant negative effect on quality of the service at $95 \%$ level of significance $(t=-0.545$, $\mathrm{p}>.05$ ). This reveals that the quality of service provided is poor and of bad quality service. This result gave credence to the findings of Ancarani (2003) who attributed provision of poor quality service to the worsening inability of traditional public organizations in meeting the needs of members of the public resulting in the entrance of the private sector into the arena of social service delivery. The results also affirm the findings of Brown, Ryan and Parker. (2000) who earlier 
established that private sector participation in service delivery has promotes competition leading to enhanced results like greater efficiency, greater value of service, a more evident attention on service users and of more exceptional for money. Hemming (2006) further acknowledged that the private sector competence in management and expertise to transform would lead to growing proficiency in service delivery.

In addition, PSP was ascertained to have insignificant negative effect at $95 \%$ level of significance on job creation $(\mathrm{t}=$ $-1.249, \mathrm{p}>.05$ ). This purports that Service providers (PSP) are not creating employment opportunities (Employability) in the course of service delivery to the various communities, thus has not led to employment multiplier Effect. This is actually the case in Nigeria today, most private service providers are more interested in profits with less workforce than to reduce their profits by recruiting workers from the respective communities. Executive members of CDAs in some rural communities reported during interviews that the poor quality services provided, negatively affect creation of jobs even in rural communities.

Furthermore, PSP was discovered to have a significant negative effect on SMEs enhancement at 95\% level of significance $(\mathrm{t}=-2.066, \mathrm{p}<.05)$. This connotes that Service providers (PSP) has increased opportunities for development of small local businesses, however, these businesses have suffered negative consequences due to bad government policies. The results support the findings of UIA (2008), who argued that SMEs are confronted with many limitations such as deficient corporate governance, inability to access finance, inadequate entrepreneurial skills, lack of general skills, poor marketing and financial planning, lack of business plans and business records, poor banking and borrowing history and a culture that disrespects business contracts marketing and financial planning, lack of business plans, lack of business records, poor banking and borrowing history and a culture that disrespects business contracts. In like manner, it was established from the results that PSP have an insignificant negative effect on improving public private partnership (PPP) for social service provision at $95 \%$ level of significance $(\mathrm{t}=-$ $0.963, \mathrm{p}>.05$ ). This suggests that Service providers (PSP) has not created a good enabling environment for enhancing public private partnership (PPP) as a major stakeholder in social service provision. Additionally, it was identified from the results that PSP have a significant negative effect on safety and security. This implies that Service providers (PSP) has not provided adequate safety and security for the various communities where they operate.

Table 5 Regression Analysis showing Effect of Private Sector Participation (PSP) on Social Service Provision (SSP) in Nigeria

\begin{tabular}{|c|c|c|c|c|c|c|}
\hline $\begin{array}{l}\text { Dependent } \\
\text { Variable }\end{array}$ & Predictor & $\boldsymbol{\beta}$ & $\mathbf{S E}$ & $\mathbf{t}$ & $\mathbf{p}$ & $\mathbf{R}^{2}$ \\
\hline \multirow[t]{2}{*}{ Accessibility } & Constant & 2.245 & .444 & 5.059 & .000 & \\
\hline & PSP & .165 & .126 & 1.310 & .195 & .029 \\
\hline \multirow[t]{2}{*}{ Availability } & Constant & 1.700 & .277 & 6.125 & .000 & \\
\hline & PSP & .021 & .079 & 0.270 & .788 & .001 \\
\hline \multirow[t]{2}{*}{ Affordability } & Constant & 2.165 & .355 & 6.103 & .000 & \\
\hline & PSP & .037 & .101 & 0.371 & .712 & .002 \\
\hline \multirow{2}{*}{ Accountability } & Constant & 2.929 & .390 & 7.510 & .000 & \\
\hline & PSP & .107 & .111 & 0.965 & .339 & .016 \\
\hline \multirow[t]{2}{*}{ Sustainability } & Constant & 1.987 & .366 & 5.431 & .000 & \\
\hline & PSP & -.154 & .104 & -1.484 & .143 & .037 \\
\hline \multirow[t]{2}{*}{ Service quality } & Constant & 2.845 & .467 & 6.087 & .000 & \\
\hline & PSP & -.072 & .133 & -0.545 & .588 & .005 \\
\hline \multirow[t]{2}{*}{ Employability } & Constant & 2.428 & .531 & 4.569 & .000 & \\
\hline & PSP & -.189 & .151 & -1.249 & .217 & .026 \\
\hline \multirow{2}{*}{$\begin{array}{l}\text { Increased } \\
\text { opportunities }\end{array}$} & Constant & 3.088 & .624 & 4.951 & .000 & \\
\hline & PSP & -.367 & .177 & --2.066 & .043 & .069 \\
\hline \multirow[t]{2}{*}{ Partnership } & Constant & 3.082 & .771 & 4.000 & .000 & \\
\hline & PSP & -.211 & .219 & -0.963 & .340 & .016 \\
\hline \multirow[t]{2}{*}{ Safety and Security } & Constant & 3.359 & .546 & 6.149 & .000 & \\
\hline & PSP & -.421 & .155 & -2.707 & .009 & .112 \\
\hline
\end{tabular}

Source: Author's Computation 
Table 6: Various Social Services Provided by Private Sectors across Communities in Nigeria

\begin{tabular}{|c|c|c|c|c|c|}
\hline Community & LGA & $\begin{array}{c}\text { Senatorial } \\
\text { District } \\
\end{array}$ & $\begin{array}{c}\text { State } \\
\text { (Geopolitical zone) } \\
\end{array}$ & Private Sector Provider & Project Provided \\
\hline Alogani South & Nasarawa-Eggon & Nasarawa North & $\begin{array}{c}\text { Nasarawa } \\
\text { (North-central) }\end{array}$ & $\mathrm{EU} / \mathrm{CBO}$ & $\begin{array}{l}\text { Built and equipped male ward in } \\
\text { Alogani health centre }\end{array}$ \\
\hline Gidan Rai & Doma & $\begin{array}{l}\text { Nasarawa } \\
\text { South }\end{array}$ & $\begin{array}{c}\text { Nasarawa } \\
\text { (North-central) }\end{array}$ & $\mathrm{EU} / \mathrm{CBO}$ & $\begin{array}{l}\text { Provision of borehole for the } \\
\text { health centre at Gidan Rai }\end{array}$ \\
\hline Katakpa & Toto & Nasarawa West & $\begin{array}{c}\text { Nasarawa } \\
\text { (North-central) }\end{array}$ & $\mathrm{EU} / \mathrm{CBO}$ & $\begin{array}{c}\text { Built a ward in the local health } \\
\text { centre }\end{array}$ \\
\hline Barri & Akko & Gombe Central & $\begin{array}{c}\text { Gombe } \\
\text { (North-east) }\end{array}$ & $\mathrm{CBO} / \mathrm{WHO}$ & $\begin{array}{l}\text { Provision of borehole equipped } \\
\text { with hand pumps at Barri }\end{array}$ \\
\hline Kanji & Nafada & Gombe North & $\begin{array}{c}\text { Gombe } \\
\text { (North-east) }\end{array}$ & $\mathrm{CBO} / \mathrm{WHO}$ & $\begin{array}{c}\text { Provision of borehole equipped } \\
\text { with hand pumps at Kanji health } \\
\text { centre }\end{array}$ \\
\hline Degri-Kufai & Balanga & Gombe South & $\begin{array}{c}\text { Gombe } \\
\text { (North-east) }\end{array}$ & $\mathrm{EU} / \mathrm{CBO}$ & $\begin{array}{l}\text { Provision of borehole equipped } \\
\text { with hand pumps and VIP } \\
\text { Latrines }\end{array}$ \\
\hline Wurno & Wurno & Sokoto East & (North-west) & $\mathrm{EU} / \mathrm{CBO}$ & $\begin{array}{l}\text { Provision of borehole equipped } \\
\text { with hand pumps and VIP } \\
\text { Latrines }\end{array}$ \\
\hline $\begin{array}{c}\text { Kware } \\
\text { Nizamiyya }\end{array}$ & Kware & Sokoto North & (North-west) & $\mathrm{EU} / \mathrm{CBO}$ & Provision of VIP Latrines \\
\hline $\begin{array}{l}\text { Sahabi Bujo } \\
\text { Islamiyya }\end{array}$ & Bodinga & Sokoto South & (North-west) & $\mathrm{EU} / \mathrm{CBO}$ & $\begin{array}{l}\text { Provision of borehole equipped } \\
\text { with hand pumps }\end{array}$ \\
\hline Mbu & Isi-Uzo & Enugu East & $\begin{array}{l}\text { Enugu } \\
\text { South-east }\end{array}$ & $\begin{array}{c}\text { Private Individual } \\
\text { (Senator Gilbert Nnaji) }\end{array}$ & $\begin{array}{c}\text { Provision of ICT laboratory at } \\
\text { Community Secondary School } \\
\text { Mbu }\end{array}$ \\
\hline Imilike Etiti & Udenu & Enugu North & $\begin{array}{c}\text { Enugu } \\
\text { South-east }\end{array}$ & $\mathrm{CBO}$ & $\begin{array}{c}\text { Built a health centre at Imilike } \\
\text { Etiti }\end{array}$ \\
\hline Ndeabor & Aninri & Enugu West & $\begin{array}{c}\text { Enugu } \\
\text { South-east }\end{array}$ & $\mathrm{CBO}$ & $\begin{array}{c}\text { Built examination hall at } \\
\text { Community Secondary Ndeabor }\end{array}$ \\
\hline Emu & Esan South East & Edo Central & $\begin{array}{c}\text { Edo } \\
\text { (South-south) } \\
\end{array}$ & Willi Johnson Foundation & Built a health centre at Emu \\
\hline Akuku & Akoko-Edo & Edo North & $\begin{array}{c}\text { Edo } \\
\text { (South-south) }\end{array}$ & Foundation Build & $\begin{array}{l}\text { Constructed bridge linking Akuku } \\
\text { with neighbouring communities in } \\
\text { the local government area }\end{array}$ \\
\hline Ugha & Uhunmwode & Edo South & $\begin{array}{c}\text { Edo } \\
\text { (South-south) } \\
\end{array}$ & Aweg & Constructed borehole at Ugha \\
\hline Aponmode & Akinyele & Oyo Central & South-west & $\mathrm{CBO}$ & Construction of coverts/drainage \\
\hline Ago Amodu & Saki East & Oyo North & South-west & $\begin{array}{c}\text { Ago Amodu } \\
\text { Development Association } \\
(\mathrm{CBO}) \\
\end{array}$ & $\begin{array}{c}\text { Construction of rural feeder roads } \\
\text { at Ago-Amodu }\end{array}$ \\
\hline Ayete & Ibarapa North & Oyo South & South-west & $\mathrm{CBO}$ & Built a health centre at Ayete \\
\hline
\end{tabular}

Sources: Authors Computation, Omofonmwan and Odia (2009 and European Union Micro Project Programme, 2009; *Geopolitical zones in parenthesis

\section{POLICY ISSUES AND CHALLENGES}

To improve the quality of life of rural communities and enhance their capacity for development, provision of social services must be ensured through the active participation of government agencies, private sector and the participation of community people. The role of the private sector in delivering social services is significant because of the specialty the private sector brings to complement public efforts.

The worst aspect of political and economic underdevelopment according to Handelman (2009) is prevalent in the rural communities of most third world nations. Most if not all rural communities in Nigeria like all third world countries are mainly agrarian in nature and are deficient in social services that characterises a typical Sub-Sahara African rural community. Handelman's view depicts a typical Nigeria's rural communities in the distribution of social services such as schools, health care, housing, electricity, safe water, adequate shelter, environmental and livelihood concerns, the rural communities lag behind, in comparison with urban centres. The social condition of the rural populace in Nigeria has long been ignored and relegated in preference to the urban environment and population.

The argument advanced in some quarters that rural areas are neglected in terms of basic social services provision, however this constraint is also more evident in the urban centres. Given that exclusion is not peculiar to rural areas, they face a much greater degree of exclusion than urban areas (Giddens, 2006). In Nigeria, the failure of government has led to the emergence of private sector. Thus, the rural population belongs to the vulnerable category as they are mostly shortchanged when it comes to provision of social services.

Spicker (2021) attest that the notion of 'empowerment' can be perceived individually, to connote the ability of each user to affect outcomes, or collectively, to indicate the status of 
vulnerable groups. Its growing importance depicts deeprooted concerns that social services may demoralise the people who use them. Deakin and Wright (1990) recommend six tests for observance to users.

(i) Accountability. This implies that services must be provided to users in such a manner that it provides satisfaction in meeting the needs of users.

(ii) Representation and participation. This connote that users/consumers should be given the opportunity to participate in decision making so that they can convey their opinions, but also that their views is given the apt attention it requires. This is often represented in terms of a 'voice' for consumers.

(iii) Information. Poor communication which implies lack of information do not allow users the privilege to express their views on issues that affect them.

(iv) Access. When users do not have the opportunity to make use of the service.

(v) Choice. This implies that when users are not given opportunity for alternatives, they may not be able to determine outcomes. This may lead to their refraining from or not utilising the service.

(vi) Redress. This may involve seeking redress for grievances, and even having contentions taking care of. This is necessary to check the use of control by agencies as well as to give users the formal opportunity to raise concerns.

\section{CONCLUSION AND RECOMMENDATIONS}

Much of the decline in government efficiency in social services provision in Nigeria has been attributed to mismanagement and corruption, non-domestication of imported policy, which has further worsened the inadequate and poor quality of the social services. Sustainable services are not provided while transparency and accountability are not adhered to when services are being provided. Service delivery by governments across the three levels of government have been very poor except for a few state governments, while the private sector has performed averagely

In view of the state of social services in Nigeria with respect to policy domestication, government at all levels need to redesign imported policy in a manner that it can function efficiently in our local environment. Country experiences show that the following policy options have the potential to improve accessibility, affordability, sustainability, accountability, availability and quality in the following ways:

Firstly, the government will need to build structures that not only enhances policy but develop an environment for the policy to create conditions that encourages private sector participation for efficient and effective service delivery.

Secondly, commercialization of social services. Instead of privatization of social service in a country where wages of workers is poor, there is need for government to embrace commercialization so that the private sector, whose main objective is profit maximization, will not exploit members of the society in the name of service delivery

Thirdly, there is need for government to promote transparency and accountability while delivering social services. Transparency and accountability are the bedrock for efficient and effective service delivery. One of the stumbling blocks to effective service delivery in Nigeria was poor accounting and records keeping, which has led to high level mismanagement and corruption.

Fourthly, need to improve the quality of social services in conformity with contemporary standards. Members of the society deserves better and quality services. Hence the need to ensure that the services provided are of high standard to meet the yearnings of members of the society.

Fifth, need to decentralize and de-institutionalise residential services and their transformation into community based services. Social services are not being rendered as community based services hence it is not appreciated at the community level and not sustainable.

Finally, need to involve the civil society and other stakeholders in in the provision of social services. The increasing population of the country also led to increasing demand for social services, which the existing ones provided by the government is not adequate to meet the needs of the society. Involving the civil society and other stakeholders would expand service providers and be able to provide adequate services.

\section{REFERENCES}

[1] Advisory Group on Civil Society (AG-CS). (2007). Civil Society and Aid Effectiveness Concept Paper. Prepared by the Advisory Group on Civil Society and AID Effectiveness of DAC.

[2] Ancarani, A, (2003). The Impact of Public Firms Commercialization on Purchasing Management, Journal Public Procurement, $3 \quad$ (3), 357-369.

[3] Asian Development Bank (ADB, 2012). Public-Private Partnership Operational Plan 2012-2020 http://www.adb.org/documents/public-privatepartnershipoperational-plan-2012-2020

[4] Ayo, B. S. (1988). Social Policy, in V. Ayeni and S. Kayode (eds.), Nigeria's Second Republic: Presidentialism, Politics and Administration in a Developing State, Lagos: Daily Times Publication.

[5] Bold, T., Collier, P. and Zeitlin, A. (2009). The Provision of Social Services in Fragile States:Independent Service Authorities as a New Modality. Oxford: Centre for the Study of African Economies, University of Oxford.

[6] Brown. K., Ryan .N. and Parker. R., (2000). New modes of service delivery in the public sector Commercialising government services. The International Journal of Public Sector Management 13(3), 206-221.

[7] Chiriacescu D., (2012). Shifting the Paradigm in Social Service Provision: Making Quality Services Accessible for People with Disabilities in South East Europe, Disability Monitor Initiative, Handicap International.

[8] Davis, J. A., (2001). Elementary Survey Analysis. Englewood Cliffs, NJ: Prentice-Hall, 1971.

[9] Deakin, N., and Wright, A. (1990). Consuming public services, Oxfordshie, England: Routledge.

[10] Donnison, D.V (1968). The teaching of Social Administration. The British Journal of Sociology, 2: 75-91. 
[11] Economic and Social Commission for Asia and the Pacific (ESCAP). (2001). The Emerging Role of the Private Sector in Delivering Social Services in the ESCAP Region. Social Policy Paper No. 4. New York: United Nations.

[12] Eurofound (2015), Delivering public services: A greater role for the private sector? An exploratory study in four countries, Luxembourg Publications Office of the European Union.

[13] European Union Micro Project Programme (2009). Micro Project Programmes (MPP) in the Niger Delta. MPP6, ec.europa.eu

[14] Geol, S.L (1981), Health Care Administration, New Delhi: Sterling Publishers Private Limited.

[15] Giddens, A. (2006). Sociology (5th ed.) Cambridge: Polity Press.

[16] Grimsey D, and Lewis M. K, (2002). Evaluating the risks of public private partnerships for infrastructure projects, International Journal of Project Management, 20: 107118.

[17] Handelman, H. (2009). The Challenges of Third World Development (5th ed). New Jersey: Pearson Prentice- Hall.

[18] Harris, C, (2003). Private Participation in Infrastructure in Developing Countries: Trends, Impacts, and Policy Lessons, $\mathrm{IBRD} / \mathrm{WB}$

[19] Hemming, R. (2006). Public-Private Partnerships, Government Guarantees and Fiscal Risk. Technical report, International Monetary Fund (IMF), Washington, DC.

[20] Hensher, D. A., and Stanley, J. (2002). Performance-Based Quality Contracts in Bus Service Provision. Sidney: Australia: Institute of Transport Studies, University of Sidney.

[21] Igbuzor, O. (2010). The Challenge of Nigeria at 50: Civil Society Perspective. A Paper Presented at the Institute of Strategic Management Annual General Meeting held at Monty Suites, Calabar, 6-8 May.

[22] Integrated Regional Information Network (IRIN). (2007). Nigeria: Basic Services a Challenge to Nigeria's New Leaders. IRIN, UN.

[23] Okojie, C. E. E. (2009). Decentralization and Public Service Delivery in Nigeria. Nigeria Strategy Support Program (NSSP) Background Paper No. NSSP 004

[24] Olewe, B.N and Anga, J.S (1994), Command Administration: The Police Perspective. Enugu: New Generation Books

[25] Omofonmwan, S. I. and Odia, L. O. (2009). The Role of NonGovernmental Organisations in Community Development: Focus on Edo State-Nigeria. Anthropologist, 11(4): 247-254

[26] Onakerhoraye, A. G. 1999. Social services in Nigeria: An introduction. London: Kegan Paul International Limited.

[27] Rwelamira, P.D, (2004). Enhancing Development in Africa: Public-Private Partnerships, Valencia, Spain: Pressgroup Holdings

[28] Spicker, P (2021), Social Administration, An introduction to Social Policy, http://spicker.uk/social-policy/socadmin.htm, obtained on 21 June 2021

[29] Thompson, L. (1995) A History of South Africa. Revised Edition. New Haven and London: Yale University Press.

[30] Todaro, M.P. \& Smith, S.C. (2007). Economic Development. Tenth Edition. Harlow: Pearson Education Limited

[31] Ugaz, C., (1999). Regulation of social services in the least developed countries: what are the issues at stake?, Working Paper No. 170, UNU/WIDER, Helsinki, December.

[32] UIA, (2008). Small and Medium Enterprises Business Guide. Uganda Investment Authority, The Republic of Uganda.

[33] UNRISD (United Nations Research Institute for Social Development, 2007). Commercialization and Globalization of Health Care: Lessons from UNRISD Research. Research and Policy, Brief No. 7. UNRISD, Geneva.

[34] World Bank. (2008). World Development Report. World Bank.

[35] World Health Organization (WHO). (2002). Understanding Civil Society Issues for WHO. Civil Society Initiatives, External relations and Governing Bodies. Discussion Paper No. 2. WHO. 